\title{
Analyses of depositional environments of the Marcellus formation in New York using biomarker and trace metal proxies
}

\author{
Reilly M. Blocho ${ }^{1,2}$ D $\cdot$ Richard W. Smith ${ }^{1,3}$ (D) Mark R. Noll ${ }^{1}$
}

Received: 7 February 2021 / Accepted: 10 July 2021 / Published online: 30 July 2021

(c) The Author(s) 2021

\begin{abstract}
The purpose of this study was to observe how the composition of organic matter (OM) and the extent of anoxia during deposition within the Marcellus Formation in New York varied by distance from the sediment source in eastern New York. Lipid biomarkers ( $n$-alkanes and fatty acids) in the extractable organic component (bitumen) of the shale samples were analyzed, and proxies such as the average chain length (ACL), aquatic to terrestrial ratio (ATR) and carbon preference index (CPI) of $n$-alkanes were calculated. Fatty acids were relatively non-abundant due to the age of the shale bed, but n-alkane distributions revealed that the primary component of the OM was terrigenous plants. The presence of shorter $n$-alkane chain lengths in the samples indicated that there was also a minor component of phytoplankton and algal (marine) sourced OM. Whole rock analyses were also conducted, and cerium anomalies were calculated as a proxy for anoxia. All samples had a negative anomaly value, indicating anoxic conditions during deposition. Two samples, however, contained values close to zero and thus were determined to have suboxic conditions. Anoxia and total organic matter (TOM) did not show any spatial trends across the basin, which may be caused by varying depths within the basin during deposition. A correlation between nickel concentrations and TOM was observed and indicates that algae was the primary source of the marine OM, which supports the lipid biomarker analysis. It was determined that the kerogen type of the Marcellus Formation in New York State is type III, consistent with a methane-forming shale bed.
\end{abstract}

Keywords Black shale $\cdot$ Biomarker $\cdot$ Depositional environment $\cdot$ Marcellus

\section{Introduction}

The Marcellus Formation, a Middle Devonian black shale, is well known as a prolific source for unconventional gas extraction, being targeted on the east coast of the USA (Kargbo et al. 2010). Gas potential is directly related to the type and amount of organic material within the sediment (Didyk et al. 1978). Black shale beds have a range of depositional facies and are known to vary widely in geochemical characteristics at different locations and depths, including in

Mark R. Noll

mnoll@brockport.edu

1 Department of Earth Sciences, State University of New York College at Brockport, Brockport, New York, USA

2 Present Address: Department of Earth and Environmental Science, New Mexico Institute of Mining and Technology, Socorro, New Mexico, USA

3 Global Aquatic Research LLC, Sodus, New York 14551, USA the amount and type of organic material present (Miceli and Philp 2012). Understanding how organic matter (OM) has been deposited, preserved and thermally altered in the Marcellus Formation and how these processes vary across New York could help target potential areas of high gas productivity. The purpose of this study is to characterize the OM within the Marcellus by analyzing distributions of chemical biomarkers in the solvent-extractable pool (bitumen) and examine how the $\mathrm{OM}$ varies with increasing distance from the sediment source (east-west), the degree of anoxia during deposition, and thermal maturation within the formation. The carbon preference index (CPI), average chain length (ACL), and aquatic to terrestrial ratio (ATR) of $n$-alkane biomarkers will be used to characterize the nature of the $\mathrm{OM}$ in the formation. Cerium anomalies will be used to determine the degree of anoxia within the basin. 


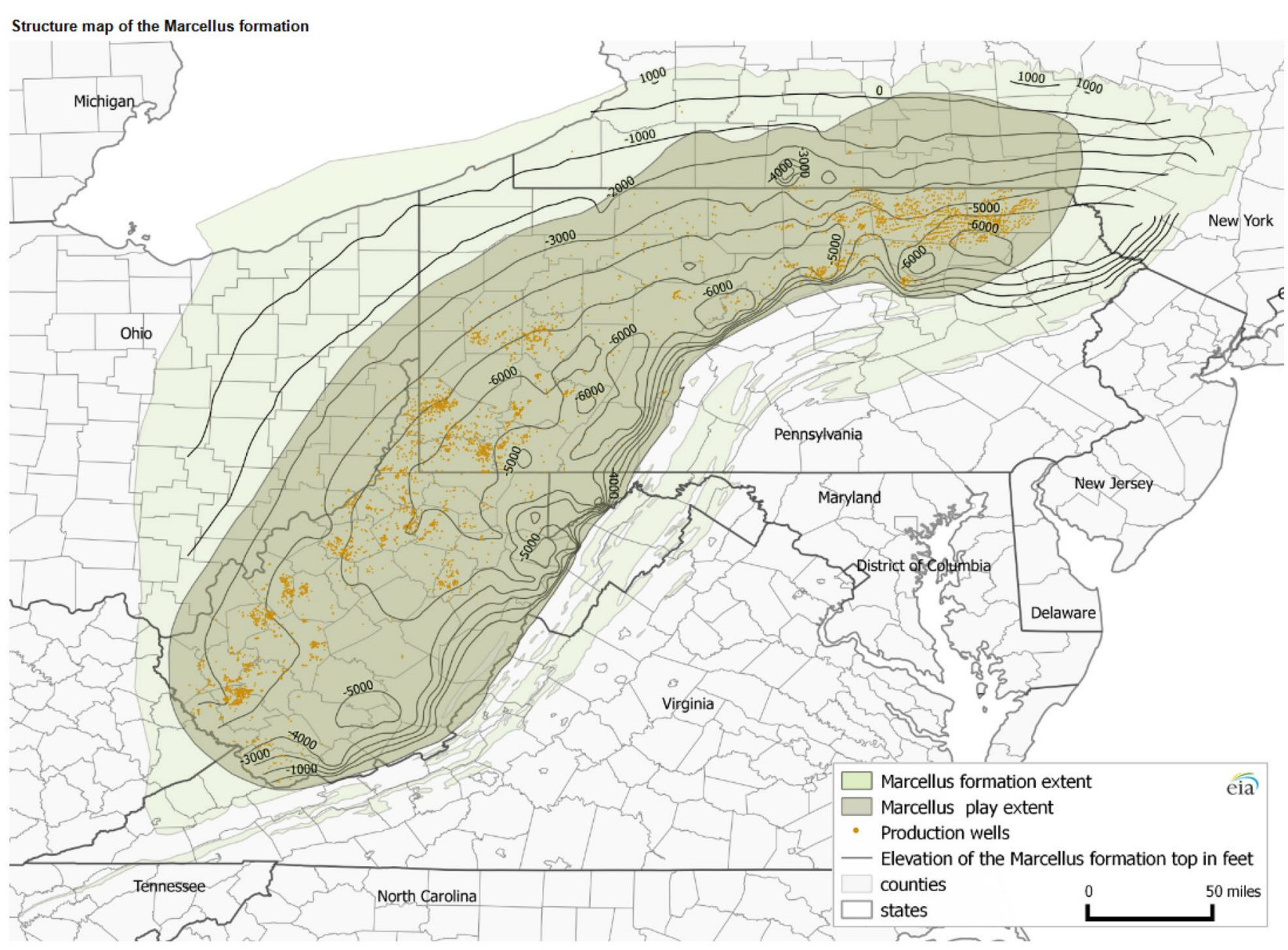

Fig. 1 Structure map of the Marcellus Formation. In New York, Pennsylvania, Maryland, Virginia, West Virginia, and Ohio. The map was acquired from the U.S. Energy Information Administration, and contains data from DrillingInfo Inc., New York State Geological Survey, Ohio State Geological Survey, Pennsylvania Bureau of Topo-

\section{Geologic setting}

The Marcellus Formation was deposited in the Middle Devonian during the Acadian orogeny in the Appalachian foreland basin that formed on the Eastern USA (Fig. 1). During this time, the Appalachian basin was also subsiding from tectonic loading of the Acadian Mountains. This subsidence, combined with sea level rise, resulted in a deep basin consisting of anoxic conditions (Griffing and Ver Straeten 1991). While this is widely accepted as the depositional conditions for the Marcellus Formation in New York, Smith, Schieber, and Wilson, (2019) suggest shallow, oxygenated water for the Appalachian basin in New York consisting of benthic life. While their model goes against previous interpretations, it is the most recent sedimentological research conducted on the Marcellus Formation in New York and deserves to be mentioned as a possible alternative for Appalachian basin graphic \& Geologic Survey, West Virginia Geological \& Economic Survey, and U.S. Geological Survey. Production wells from January 2003 through December 2014 are used in the map. The contour lines represent the elevation of the Marcellus Formation top with a 1000foot contour interval (Popova, et al., 2015, April 1)

depositional conditions in New York during this time. Sediments eroding from the Acadian Mountains were transported via the Catskill Delta and deposited into the Appalachian basin (Mazzullo, 1973, Driese et al. 1997). The Marcellus Formation is therefore thicker in Eastern New York and thinner to the west (Lash and Engelder 2011). In New York, the Marcellus formation outcrops roughly parallel to the coast of Lake Ontario, dipping roughly two degrees toward the south into Pennsylvania (Fig. 1). The Marcellus Formation overlies the Onondaga Limestone, which is composed of patch reefs, and the boundary between the two formations marks the time when the basin subsidence and sea level rise begins (Griffing and Ver Straeten 1991). The Skaneateles Formation overlies the Marcellus Formation and signifies subsequent sea-level lowering and the return to oxic conditions (Werne et al. 2002).

Three members make up the Marcellus Formation: the Union Springs Shale, which is the deepest, the Cherry Valley 


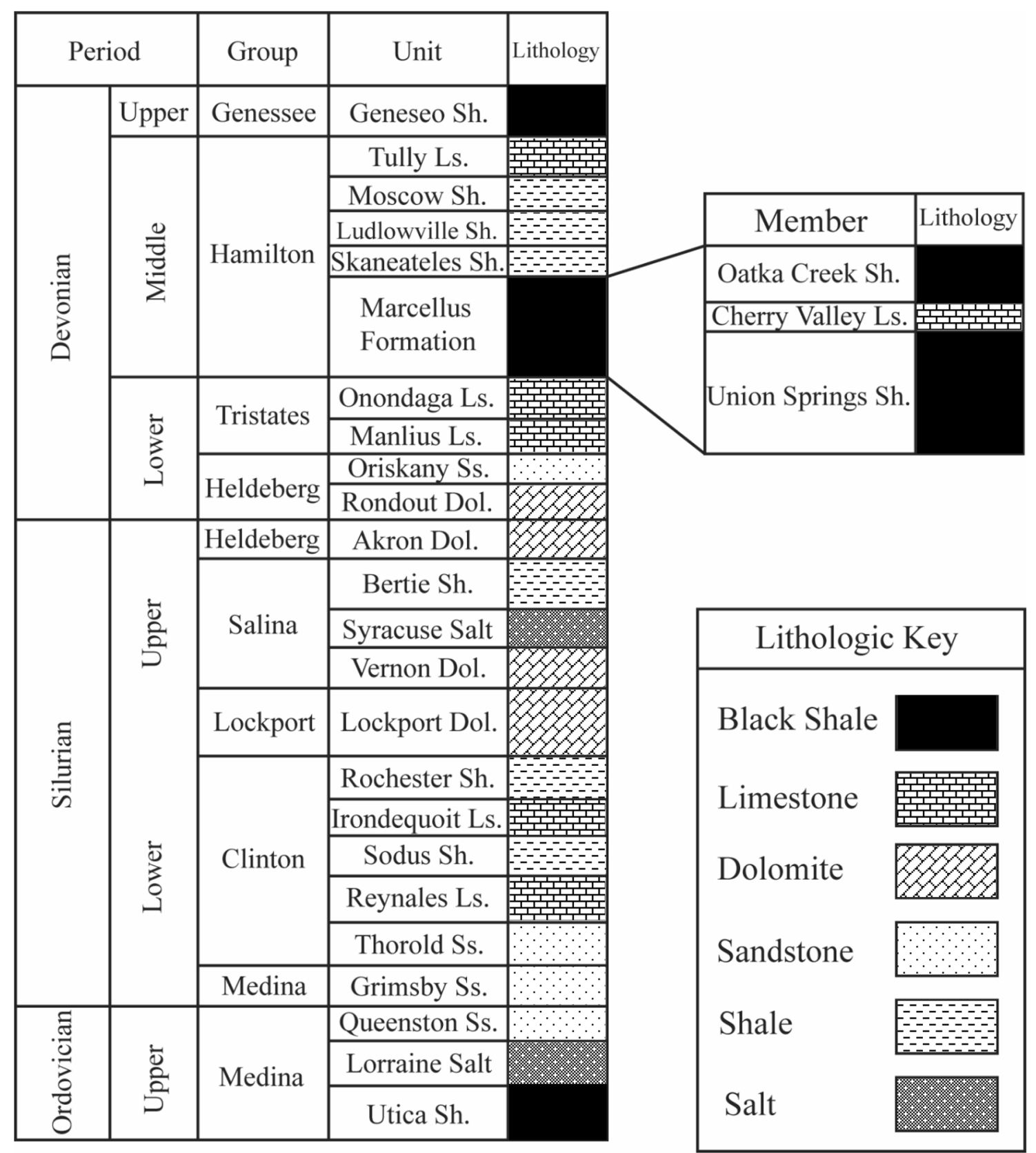

Fig. 2 A general stratigraphic column of the stratigraphy of New York State from the Upper Ordovician to the Upper Devonian, modified from (Nyahay et al., 2007). Note that while the Marcellus is the most well-known black shale, New York also contains the Utica and Geneseo Shales

Limestone, and the Oatka Creek Shale which is the uppermost member (Fig. 2). The Union Springs and the Cherry Valley Limestone members, however, are not observed in a portion of western New York (both being absent in almost the same locations), while the Oatka Creek shale is present across the entire state (Lash and Engelder 2011). In Central and Western New York, portions of the Cherry Valley Limestone and the Upper part of the Union Springs member are difficult to distinguish, which has led to incorrect thickness values for the Cherry Valley Limestone (Griffing and Ver Straeten 1991). 
Both the Union Springs and the Oatka Creek members have been targeted for hydrocarbons.

\section{Background}

Multiple studies have been conducted on the gas potential of black shales by using biomarker ratios to determine characteristics of the OM (Ayyıldiz et al. 2019, Agrawal and Sharma 2018, Gao et al. 2020, Miceli and Philp 2012, $\mathrm{Qu}$ et al. 2017). Biomarkers, classes of organic compounds with a known source, have been used to determine the gas potential of black shales because of the amount of information they contain related to OM source and depositional environment (Bianchi et al. 2016). Preserved compounds can be indicative of a marine or terrigenous OM origin, inputs from specific types of algae, plants and bacteria, and the degree of maturation that the $\mathrm{OM}$ within a source rock has undergone (Meyers 1997, Mani et al. 2017). The usefulness of biomarkers and other indicators to determine the potential of source rocks around the world has been demonstrated by Gao et al. (2020), Qu et al. (2017) and many others. While biomarkers may degrade due to diagenesis (Tissot et al. 1987, Mißbach et al. 2016), biomarkers such as n-alkanes are more resistant to changes caused by these processes (Meyers 1997), and have long been used to determine the source and maturity of kerogen (Bray and Evans 1961, Peters et al. 2005).

Multiple studies on the Marcellus Formation have been conducted across eastern North America to determine gas potential. Obermajer et al. (1997) evaluated the Marcellus in Ontario, Canada, and determined the source of the OM to be marine and the kerogen as type II. The deposition of large amounts of OM to this region of the Marcellus was from high productivity of marine plankton, as well as anoxic conditions in bottom water which increased preservation. This organic material was deposited in a shelf environment that was transitioning to a basin setting, and the reduction of dissolved oxygen was caused by a lack of circulation within the basin. Optical properties evaluated in Obermajer et al. (1997) showed that the Marcellus reached the early stages of oil formation, which was also supported by biomarker ratios. This study further validates the use of biomarkers in mature shales, and it will allow for a comparison in the variability of the Marcellus Formation.

There are various types of biomarkers that have been utilized to evaluate organic material to gain insight in the source of organic material, thermal maturation of source rocks, and other basin characteristics. One type of biomarker is n-alkanes. These compounds are hydrogen saturated, straight chain hydrocarbon, usually referred to by chain length (Kostecki et al. 2005), and commonly preserved within the organic matter found in shales. These organic compounds come from bacteria, archaea, and eukaryotes. They are also produced by the breakdown of biolipids such as fatty acids, esters, alcohols, alkenes, plant waxes and polymethylenic biopolymers (Grice and Eiserbeck 2013). Since these organic compounds and biolipids have a specific organic signal, the concentration of certain n-alkanes found in the organic material of a shale can be used to determine what was the source of organic material (e.g., marine or terrestrial). This information can then be further used to determine basin conditions.

Other basin characteristics can be determined by looking at trace elements within the sediments. Ratios of these trace metals may give vital pieces of information to help understand the depositional environment, such as anoxia, and other basin characteristics (Quinby-Hunt et al. 1989). Lewan and Maynard (1982) discuss the sources of enrichment of nickel and vanadium within organic-rich rocks and what these enrichments indicate about the depositional environment, providing important information when determining how a basin varies with respect to OM. Nickel enrichment in black shales was determined to be caused by algae absorbing nickel within the ocean water (Lewan and Maynard 1982). Chen and Sharma (2016) also determined that there is variability in concentrations of trace metals such as $\mathrm{U}, \mathrm{Mo}$, and $\mathrm{V}$ in organic-rich sections of the Marcellus Formation due to oscillations in redox conditions during deposition.

Werne et al. (2002) used a combined trace metal and geochemical proxy approach in the Oatka Creek member, the upper member of the Marcellus Formation in Western New York, to determine characteristics of the depositional environment. They also successfully used proxies such as the ratio of molybdenum to titanium (Mo/Ti), iron to titanium (Fe/Ti), and the concentration of organic carbon (Corg) to determine sea level during deposition. The investigation determined that redox indicators are more prominent in the Oatka Creek member because of sea level rise restricting the deposition of carbonate muds to the basin. It was also determined that euxinic conditions existed during deposition due to sea level rise.

\section{Objectives}

The purpose of this study is to characterize the $\mathrm{OM}$ within the Marcellus by analyzing distributions of chemical biomarkers in the solvent-extractable pool (bitumen) and examine how the $\mathrm{OM}$ varies with increasing distance from the sediment source (east-west), the degree of anoxia during deposition, and thermal maturation within the formation. The carbon preference index (CPI), average chain length (ACL), and aquatic to terrestrial ratio (ATR) of $n$-alkane biomarkers will be used to characterize the nature of the $\mathrm{OM}$ in the formation. Cerium anomalies will be used to determine the degree of anoxia within the basin. 


\section{Methodology}

\section{Sampling}

Seven samples of the Marcellus Formation were obtained from outcrops along an east-west transect from Richfield Springs, NY to Leroy, NY (Fig. 2). Five samples were taken from road cuts. Two samples (M2, and M3) were collected from Callanan Quarry and the Seneca Stone Quarry, respectively. All seven samples are used in the inorganic analysis; however, due instrumental error, the data for sample four (M4) are not reported in the organic analysis.

Shale samples were trimmed by hand to obtain an unweathered sample. The unweathered inner core of the original sample was broken into smaller chips, which were pulverized using a Spex Mixer Mill 8000 for 45 min to achieve particles less than 270-mesh (Fig. 3).

\section{Lipid analysis (biomarkers)}

Lipid analysis procedures were modified from Canuel and Martens (1993). Roughly $1.5 \mathrm{~g}$ of sample was placed in steel vials and surrounded by combusted sand. OM was extracted using a Dionex Accelerated Solvent Extraction 150 system (ASE) with 65\% dichloromethane (DCM) and 35\% methanol (MeOH) by volume at $80^{\circ} \mathrm{C}$ and $\sim 1600$ psi.

The lipid isolation procedure was modified from Bligh and Dyer (1959). The volumes of solvent in the ASE vials were adjusted to a final 1:1:0.9 solution of DCM/ $\mathrm{MeOH} / 20 \% \mathrm{NaCl}$ in water. The solvent mixtures were then poured into $250-\mathrm{mL}$ separatory funnels, shaken for $1 \mathrm{~min}$, and allowed to stand for $1 \mathrm{~h}$. Two layers formed: an organic layer containing the lipids in the bottom layer, and an aqueous layer on top. The organic layer was then drained and kept. $60 \mathrm{~mL}$ of hexane was then added to each separatory funnel, which were again shaken for $1 \mathrm{~min}$ and allowed to stand for $1 \mathrm{~h}$. After separation, the top organic layer containing the lipids was added to the first organic fraction. The combined fractions were concentrated using rotary evaporation to $\sim 10 \mathrm{~mL}$, transferred to pre-weighed vials, and evaporated under a steady stream of $\mathrm{N}_{2}$ until dry. The residue is considered the total lipid extract (TLE). The final weight of the vials was measured, and the weight difference was used to estimate percent total lipids by weight in each sample.

The TLEs were dissolved using $100 \mu \mathrm{L}$ of hexane, and the solution was transferred to $15-\mathrm{ml}$ centrifuge tubes and evaporated to dryness with $\mathrm{N}_{2}$. Next, $3 \mathrm{~mL}$ of potassium hydroxide was added to each tube, which were then sealed under $\mathrm{N}_{2}$ and placed in the oven for saponification at $110{ }^{\circ} \mathrm{C}$ for $2 \mathrm{~h}$.

To isolate $n$-alkane hydrocarbons, $5 \mathrm{~mL}$ of hexane and $3 \mathrm{~mL}$ of pure (Milli- $Q$ ) water were added to the saponified mixtures, which were shaken for $1 \mathrm{~min}$ and allowed to stand for $1 \mathrm{~h}$. The top organic layer was pipetted out and transferred into another set of $15-\mathrm{mL}$ centrifuge tubes. Another $5 \mathrm{~mL}$ of hexane was added to the original vials, which were again shaken for $1 \mathrm{~min}$ and allowed to stand for $1 \mathrm{~h}$, and the top organic layer was also added to the new set of vials containing the first extract.

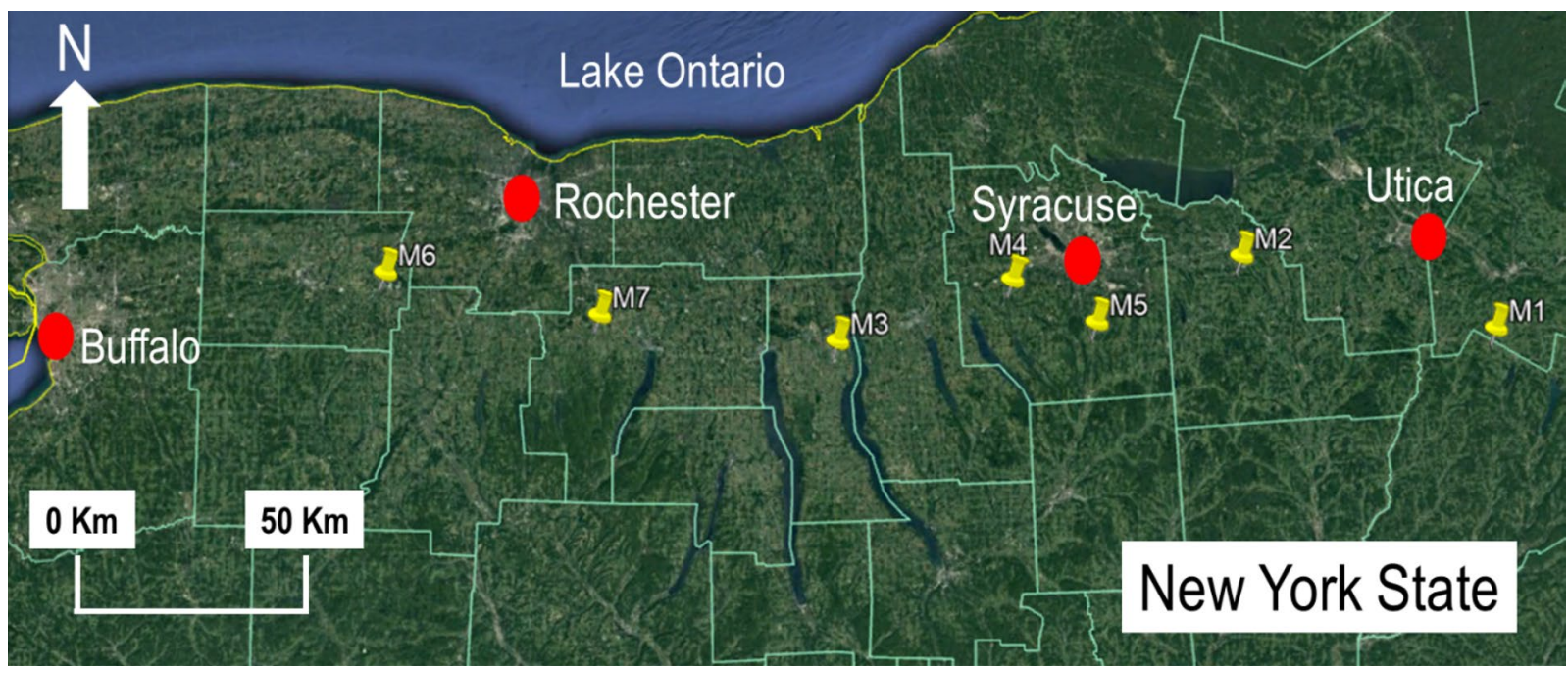

Fig. 3 Map of sample locations which closely follows the outcrop pattern of the Marcellus Formation, M2 and M3 are quarry cuts taken from Callanan Quarry and Seneca Stone Quarry, respectively, while the rest of the samples are taken from outcrops and road cuts. Image from Google Earth Pro V 7.3.3.7786. (December 2016). New York, USA. $42^{\circ} 42^{\prime} 34.37^{\prime \prime}$ N, $76^{\circ} 51^{\prime} 08.66^{\prime \prime} \mathrm{W}$ Eye alt $202.51 \mathrm{mi}$. NOAA. Google 2020 [Accessed July 28th, 2020 
To isolate fatty acids, $3 \mathrm{~mL}$ of $3 \mathrm{M} \mathrm{HCl}$ were added to the saponified aqueous layer left over after $n$-alkane extraction and were shaken for $1 \mathrm{~min}$ and let stand for $1 \mathrm{~h}$. The top organic layer was transferred into an empty vial. This was then repeated with another $5 \mathrm{ml}$ of hexane, combining both extracts.

\section{GC/MS analysis}

The fatty acid and $n$-alkane extracts were dried under $\mathrm{N}_{2}$, reconstituted into $\sim 150 \mathrm{ul}$ hexane, and injected onto an Agilent 7890a/5979 gas chromatograph/mass spectrometer equipped with either a DB/WAX-ETR column (for fatty acids) or a DB-5 column (for $n$-alkanes). Fatty acid data are not reported due to few compounds above the limit of detection. $\mathrm{N}$-alkanes were identified by comparison to an external standard containing a range of even-chained $n$-alkanes, as well as by comparison with published mass spectra. $\mathrm{m} / \mathrm{z} 57$ peaks were integrated to determine compound abundances, as these ions showed minimal overlap with co-eluting compounds and were the most abundant ions in the n-alkane spectra. The ratio of a compound's $\mathrm{m} / \mathrm{z} 57$ peak area to its concentration in the standard solution was used to correct its integrated peak area in a sample, thus correcting for differences in $\mathrm{m} / \mathrm{z} 57$ ion production. Due to a lack of known extraction efficiencies, absolute concentrations are not reported. Instead, percent relative abundances of each compound are calculated from the ratio of all normalized $\mathrm{m} / \mathrm{z} 57$ peak areas in a sample.

\section{Organic matter}

The OM content of each sample was determined by loss on ignition (LOI) (Xie, Dearing, and Blomendal 2000). Approximately five grams of powdered sample was placed in a massed crucible and dried at $100{ }^{\circ} \mathrm{C}$ to constant weight. After drying, the samples were ignited in an oven at $550{ }^{\circ} \mathrm{C}$ for $4 \mathrm{~h}$. Loss on ignition was determined by comparing weights before and after ignition, and reported as percent total organic matter (\% TOM).

\section{Whole rock analysis}

Whole rock analyses were completed by ACTLABS located in Ancaster, Ontario following method Lithogeochemistry Total IDENT 4E-expl. The following trace metals were determined by Instrumental Neutron Activation Analysis (INAA): $\mathrm{As}, \mathrm{Au}, \mathrm{Br}, \mathrm{Ce}, \mathrm{Co}, \mathrm{Cr}, \mathrm{Cs}, \mathrm{Eu}, \mathrm{Hf}, \mathrm{Hg}$, Ir, La, Lu, Mo, Nd, Rb, Sb, Sc, Se, Sm, and Ta. Multielement INAA and total digestion inductivity coupled plasma (MULT INAA / TD-ICP) were used for Ag, and
MULT INAA/ fusion inductivity coupled plasma (FUSICP) was used for $\mathrm{Ba}$. TD-ICP was used for $\mathrm{Ba}, \mathrm{Bi}, \mathrm{Cd}$, $\mathrm{Cu}, \mathrm{Ni}, \mathrm{S}, \mathrm{Zn}$, while $\mathrm{Be}, \mathrm{Sr}, \mathrm{V}, \mathrm{Y}, \mathrm{Zr}, \mathrm{Al}_{2} \mathrm{O}_{3}, \mathrm{CaO}, \mathrm{Fe}_{2} \mathrm{O}_{3}$, $\mathrm{K} 2 \mathrm{O}, \mathrm{MgO}, \mathrm{MnO}, \mathrm{Na}_{2} \mathrm{O}, \mathrm{P}_{2} \mathrm{O}_{5}, \mathrm{SiO}_{2}, \mathrm{TiO}_{2}$, and LOI were analyzed by FUS-ICP.

\section{Biomarker/Trace metal proxy formulas}

ACL was calculated according to Eq. 1 (Poynter and Eglinton 1990):

$\mathbf{A C L}_{15-33}=\frac{\sum\left(C_{n} \times n\right)}{\sum C_{n}}$

where $C_{n}$ is the relative abundance of the specified $n$-alkane and $\mathrm{n}$ is the number of carbons within each $n$-alkane. Only chain lengths 15 to 33 are used in the equation. The ACL indicates the average chain length (the average amount of carbon atoms) of the $n$-alkanes within each sample. Organic compounds that are marine sourced have lower ACL values from chain lengths 14 to 24 (Meyers and Ishiwatari, 1993), while terrestrial sourced organic compounds have higher ACLs that range from 21 to 39 (Eglinton and Hamilton 1967, Jeng 2006).

The ATR characterizes the relative amounts of marine and terrestrially sourced OM. The equation is the inverse of Meyers (1997) terrigenous to aquatic ratio (TAR) and is calculated as:

$$
\mathbf{A T R}=\frac{\left(n-C_{15}+n-C_{17}+n-C_{19}\right)}{\left(n-C_{27}+n-C_{29}+n-C_{31}\right)}
$$

where $C_{n}$ is the relative abundance of the specified $n$-alkane and $n$ is the number of carbons within each $n$-alkane. Values less than 1 indicate terrestrial dominated $\mathrm{OM}$, and values greater than one indicate marine dominated OM.

The CPI compares the ratio of odd to even $n$-alkanes and is used to help determine both the source of OM and the extent of thermal maturation (Bray and Evans 1961). High CPI 5-10 indicates terrestrial sourced organic material; however, this value will become closer to 1.0 if the organic material has undergone more maturation (El Nemr et al. 2016, Theresa et al. 2018). Marine microorganisms and recycled organic matter will also result in CPI values close to one (Kennicutt II et al. 1987). Petrogenic input will have a CPI less than one (El Nemr et al. 2016). The CPI is calculated as follows, from Bray and Evans (1961):

$$
\mathbf{C P I}_{16-32}=\frac{1}{2} \times\left(\frac{\left(\sum_{\text {odd }} C_{17-31}\right)}{\left(\sum_{\text {even }} C_{16-30}\right)}+\frac{\left(\sum_{\text {odd }} C_{17-31}\right)}{\left(\sum_{\text {even }} C_{18-32}\right)}\right)
$$

where $C_{n}$ is the relative abundance of the specified n-alkane of chain lengths 16 to 32 . 
Cerium (Ce) anomalies indicate the amount of anoxia within a basin during deposition. In rare earth element (REE) calculations, REE concentrations are normalized to a standard. It is then assumed that REE concentrations decline with increasing atomic number. The Ce anomaly is determined by the divergence of $\mathrm{Ce}$ concentrations from this trend which is determined by comparing concentrations to the adjacent REE ( $\mathrm{La}$ and $\mathrm{Pr}$ in this circumstance). Ce is used for the anomaly because other than europium, it is the only rare earth element that is redox sensitive in depositional environments (Quinby-Hunt et al. 1989). So, the preservation of cerium can be used as a proxy for anoxic conditions according to the following equation from Quinby-Hunt et al. (1989):

Cerium Anomaly $=\log \left(\frac{2 \times \mathrm{Ce}}{\mathrm{La}+\mathrm{Pr}}\right)$

where $\mathrm{Ce}$ is the cerium concentration, $\mathrm{La}$ is the lanthanum concentration, and $\mathrm{Pr}$ is the praseodymium concentration in each sample, all of which were normalized to chondrites. Negative values indicate anoxic conditions, while positive values indicate oxic conditions. Values that are less negative indicate less anoxic conditions (Quinby-Hunt et al. 1989).
Table 2 A table characterizing the hydrocarbon potential of organic sediments given the weight percentage of the total organic carbon content of a rock

\begin{tabular}{ll}
\hline Total organic carbon (content weight \%) & $\begin{array}{l}\text { Hydrocarbon } \\
\text { generation } \\
\text { potential }\end{array}$ \\
\hline Less than 0.5 & Very Poor \\
$0.5-1.0$ & Poor \\
$1.0-2.0$ & Fair \\
$2.0-4.0$ & Good \\
$4.0-12.0$ & Very good \\
Greater than 12.0 & Excellent \\
\hline
\end{tabular}

The higher TOC within a source rock, the higher hydrocarbon generation potential that rock has (Mani, D., Kalpana, M. S., Patil, D. J., \& Dayal, A. M. 2017 Organic Matter in Gas Shales: Origin, Evolution, and Characterization. In Shale Gas pp. 25-54)

\section{Results}

Total organic matter (\%TOM) in the shales ranged from $2.43 \%$ to $14.46 \%$ (Table 1). Along the sampling transect, some spatial variability was seen (Fig. 6, Table 5) with the highest \% TOM concentrations in sample M2: approximately twice as high as the next highest concentration. The lowest concentrations are found in samples M1, M5 and M7 (Table 2).
Table 1 A chart characterizing the kerogen type of certain depositional environments

\begin{tabular}{|c|c|c|c|c|}
\hline $\begin{array}{l}\text { Depositional } \\
\text { Environment }\end{array}$ & $\begin{array}{l}\text { Kerogen } \\
\text { Type }\end{array}$ & Maceral Type & Origin & $\begin{array}{l}\text { Hydrocarbon } \\
\text { Potential }\end{array}$ \\
\hline \multirow{3}{*}{ Aquatic } & \multirow[b]{2}{*}{ I } & Alginite & Algal bodies & \multirow{4}{*}{ Oil } \\
\hline & & & $\begin{array}{l}\text { Structureless debris } \\
\text { of algal bodies }\end{array}$ & \\
\hline & \multirow{2}{*}{ II } & organic matter & $\begin{array}{l}\text { Structureless, planktonic } \\
\text { material, primarily of } \\
\text { marine origin }\end{array}$ & \\
\hline \multirow{3}{*}{ Terrestrial } & & Exinite & $\begin{array}{l}\text { Skins of spores and } \\
\text { pollen, cuticle of leaves, } \\
\text { herbaceous plants }\end{array}$ & \\
\hline & III & Vitrinite & $\begin{array}{l}\text { Fibrous and woody plant } \\
\text { fragments and structureless } \\
\text { colloidal humic matter }\end{array}$ & $\begin{array}{l}\text { Gas and } \\
\text { some oil }\end{array}$ \\
\hline & IV & Inertinite & $\begin{array}{l}\text { Oxidized rexycled } \\
\text { woody debris }\end{array}$ & None \\
\hline
\end{tabular}

The hydrocarbon potential of each kerogen type is given as well as the source of the organic matter. (Mani, D., Kalpana, M. S., Patil, D. J., \& Dayal, A. M. 2017 Organic Matter in Gas Shales: Origin, Evolution, and Characterization. In Shale Gas pp. 25-54) 


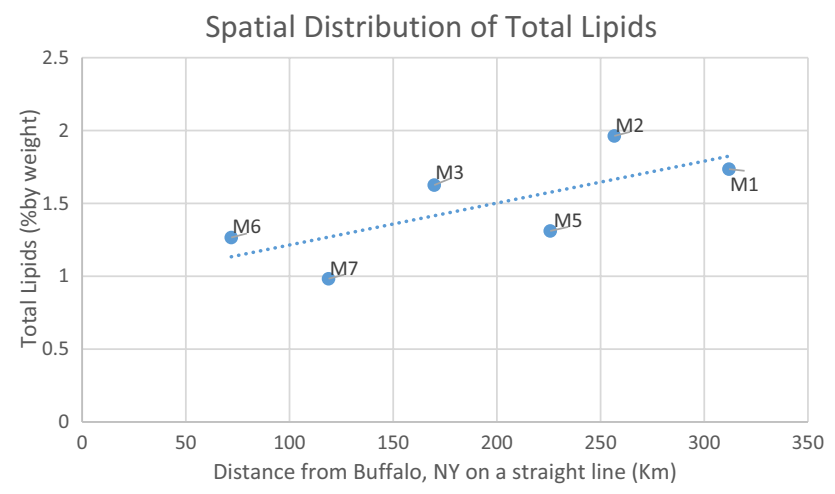

Fig. 4 Total lipid variation in samples along the transect of New York State. In general, total lipids increase from west to east, moving across the paleobasin toward the primary sediment source area. An $\mathrm{R} 2$ of 0.5159 for a line of best fit was determined

The percent total lipids by weight in the shale samples ranged from $0.98 \%$ to $1.96 \%$ and appear to generally increase east across the state (Fig. 4, Table 4). n-Alkanes were found with chain lengths ranging from 10 (C10) to 35 (C35) carbon atoms (Table 3). Three distinct patterns in chain length distributions were observed (Fig. 5). M2 and
M5 both contain only one large peak centered at C25-26, while M3 shows two distinct peaks: one larger peak centered at $\mathrm{C} 25-26$ and a smaller peak centered at C17. M1, M6, and M7 contain two peaks, similar to M3; however, these peaks are "connected" by intermediate chain lengths rather than showing two distinct peaks. Degradation of OM may explain the overlap in these distinct peaks, resulting in wider peaks and shorter chain lengths as carbon atoms are cleaved by demethylation (Fig. 6).

Despite the differences in lipid concentrations and n-alkane peak distributions, biomarker proxies varied little among samples (Table 4 ). ACL values were $\sim 25$ for each sample, ranging from 24.64 (M6) to 26.71 (M5). ATRs ranged from 0.62 (M6) to 0.86 (M5), and CPI values ranged from 0.99 (M5) to 1.04 (M4).

Cerium anomalies ranged from -0.01 to -0.14 , showing spatial variations in anoxia across New York (Fig. 7, Table 5). Spatial trends were not observed for anoxia across New York State however.

Nickel concentrations ranged from 13 to 297 (mg/kg). A relationship was observed between Nickel and TOM (Fig. 8), with an $R^{2}$ of 0.945 .
Table 3 Relative abundances of $n$-alkanes within each sample

\begin{tabular}{lrrrrrr}
\hline$n$-Alkanes & M1 & M2 & M3 & M5 & M6 & M7 \\
\hline C10 & 0.00 & 0.00 & 0.00 & 0.00 & 0.00 & 0.00 \\
C11 & 0.00 & 0.00 & 0.00 & 0.00 & 0.00 & 0.00 \\
C12 & 0.10 & 0.00 & 0.00 & 0.00 & 0.00 & 0.00 \\
C13 & 0.22 & 0.00 & 0.00 & 0.00 & 0.12 & 0.00 \\
C14 & 0.66 & 0.00 & 0.00 & 0.00 & 0.79 & 0.00 \\
C15 & 0.64 & 0.00 & 0.00 & 0.00 & 3.85 & 2.48 \\
C16 & 0.66 & 0.00 & 1.11 & 0.04 & 2.45 & 0.65 \\
C17 & 1.42 & 0.05 & 3.42 & 0.08 & 3.16 & 1.33 \\
C18 & 2.59 & 0.16 & 4.32 & 0.13 & 3.29 & 1.79 \\
C19 & 2.76 & 0.24 & 3.71 & 0.20 & 3.31 & 2.28 \\
C20 & 3.35 & 0.40 & 2.13 & 0.28 & 3.00 & 2.37 \\
C21 & 3.25 & 1.38 & 1.32 & 0.91 & 3.50 & 3.03 \\
C22 & 5.44 & 3.64 & 2.29 & 2.51 & 3.79 & 4.64 \\
C23 & 8.11 & 7.49 & 4.54 & 5.66 & 5.68 & 6.81 \\
C24 & 9.88 & 11.95 & 8.27 & 10.04 & 7.82 & 10.06 \\
C25 & 11.31 & 14.35 & 11.18 & 13.28 & 9.74 & 12.07 \\
C26 & 9.80 & 15.72 & 13.57 & 16.09 & 11.07 & 13.15 \\
C27 & 8.75 & 13.38 & 12.45 & 14.68 & 10.35 & 11.28 \\
C28 & 7.58 & 10.41 & 9.98 & 12.26 & 8.72 & 9.08 \\
C29 & 6.60 & 8.21 & 8.03 & 9.59 & 7.24 & 7.05 \\
C30 & 4.63 & 5.26 & 5.25 & 6.06 & 4.80 & 4.96 \\
C31 & 3.82 & 3.22 & 3.33 & 3.72 & 3.41 & 3.18 \\
C32 & 3.39 & 1.84 & 2.59 & 2.12 & 1.78 & 1.57 \\
C33 & 2.31 & 1.10 & 1.30 & 1.30 & 1.06 & 0.98 \\
C34 & 1.41 & 0.76 & 0.77 & 0.68 & 0.66 & 0.73 \\
C35 & 1.30 & 0.44 & 0.44 & 0.36 & 0.38 & 0.53 \\
\hline & & & & & \\
& & & & & \\
\end{tabular}


M1

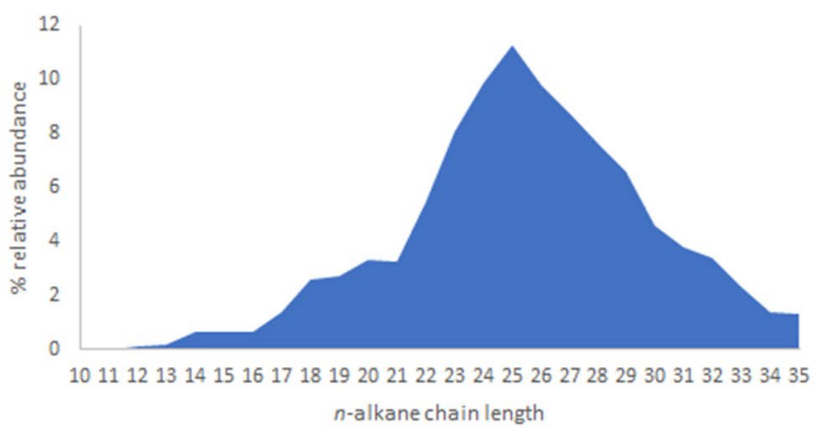

M2

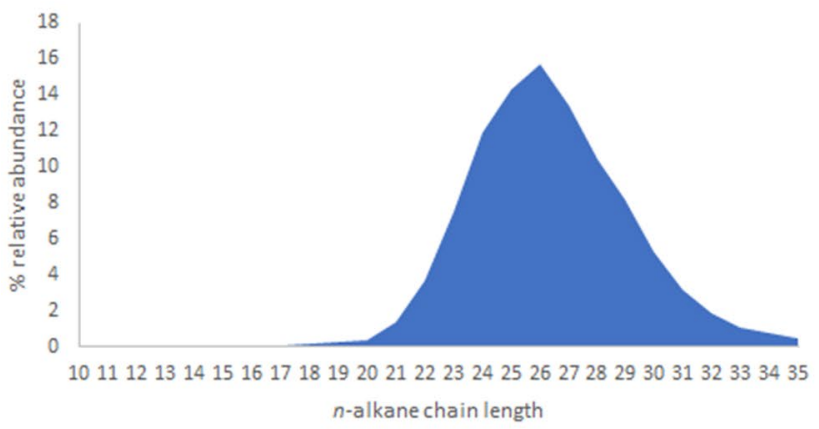

M3

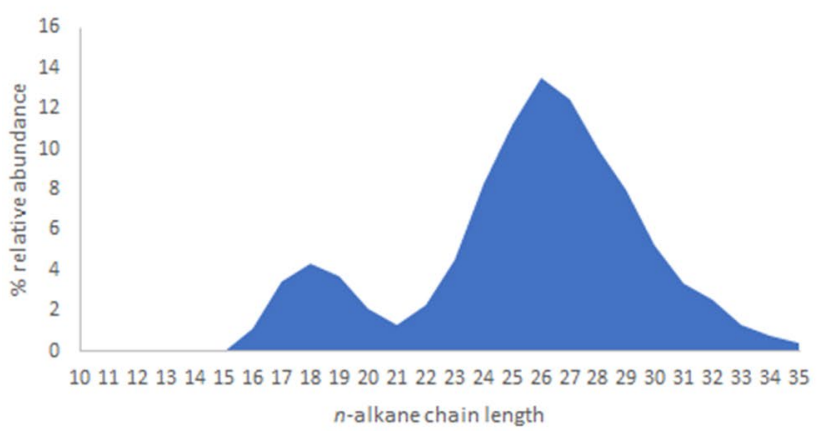

Fig. 5 Relative abundance distribution of n-alkanes of each sample. Two trends are observed below. The first trend shown in M1, M2, M5 has a large single peak centered around chain length 25 , indicating organic material with a terrigenous source. The other trend shown in

\section{Discussion}

The relatively constant ACL values of the-n-alkanes across the Marcellus transect in New York State $(\sim 25$, Table 4$)$ suggest that the majority of the $\mathrm{OM}$ is terrestrial in origin (Bianchi and Canuel 2011). A plot of the relative abundance of each n-alkane in the samples (Fig. 5) shows that samples have a bimodal distribution in chain lengths, with a second smaller peak centered around C14 to C18 in M1, M6, M3 and M7. This would suggest that the organic material within these samples is a combination of marine and terrestrial sourced organic material (Bianchi and Canuel 2011). The
M5

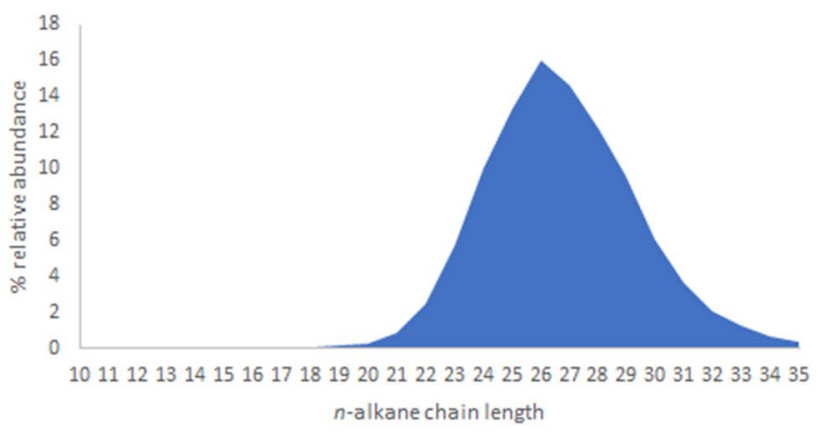

M6

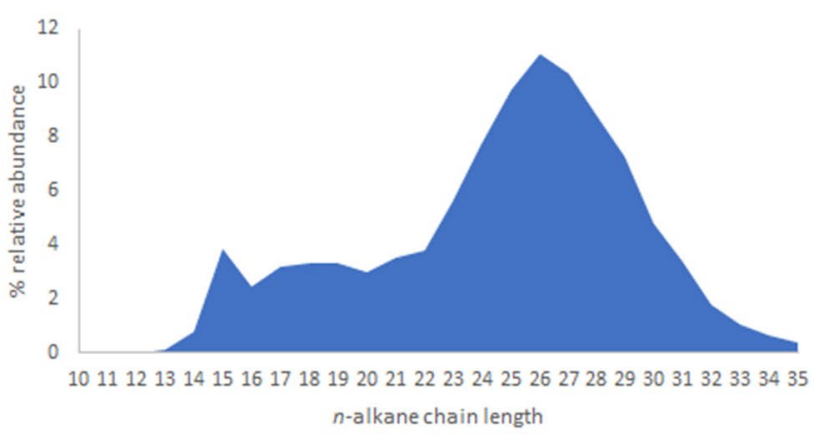

M7

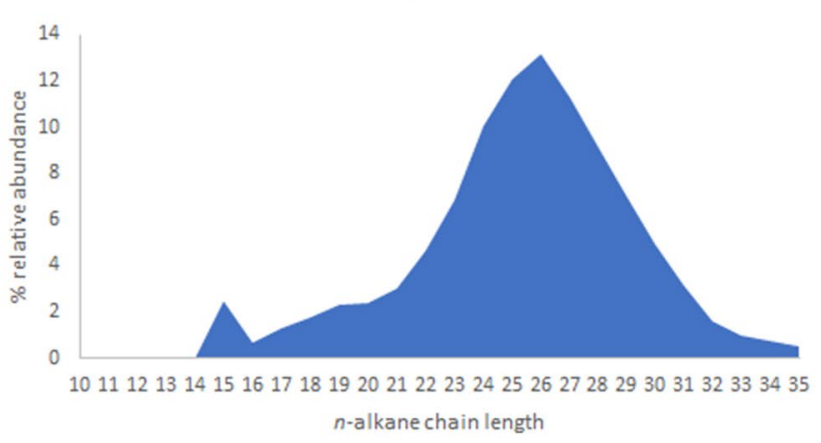

M3, M6, and M7 consists of two peaks, a large peak centered around chain length 25 indicative of terrigenous organic material and a smaller, minor peak centered around chain length 15, 16, and 17 indicating marine sourced organic material

ATR ratios were all less than one (Table 4), which supports that there is a greater component of terrigenous material that is making up the OM in M1, M6, M3, and M7. Simoneit (1977) observed similar results, where some samples contained bimodal peaks where terrestrial sourced material was the main component of organic material with a minor component of marine material.

The CPI values in every sample were close to 1 (Table 4), which suggests two possibilities. These low values may reflect a mature source rock with petroleum production potential (Bianchi and Canuel 2011). This would place our samples in the late oil window to wet gas 


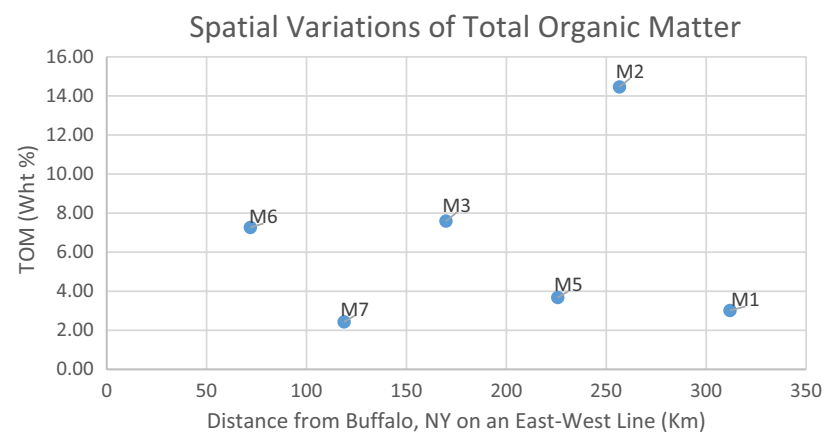

Fig. 6 Variations in total organic matter content of the sediment along the west to east transect across New York State. This may be related to the local water depth or depositional environment

Table 4 The calculated average chain length (ACL), carbon preference index (CPI), aquatic to terrestrial ratio (ATR) and the percent lipids by weight are shown below

\begin{tabular}{lllll}
\hline & ACL & CPI & ATR & $\begin{array}{l}\text { \% Lipids } \\
\text { by weight }\end{array}$ \\
\hline M6 & 24.64 & 1.04 & 0.62 & 1.27 \\
M7 & 25.37 & 1.00 & 0.69 & 0.98 \\
M3 & 25.57 & 1.01 & 0.69 & 1.63 \\
M5 & 26.71 & 0.99 & 0.86 & 1.31 \\
M2 & 26.37 & 1.00 & 0.82 & 1.96 \\
M1 & 25.49 & 1.02 & 0.68 & 1.74 \\
\hline
\end{tabular}

Note that these are listed by spatial distribution along a transect from Buffalo, New York where M6 is the closest and M1 is the farthest away from Buffalo, New York

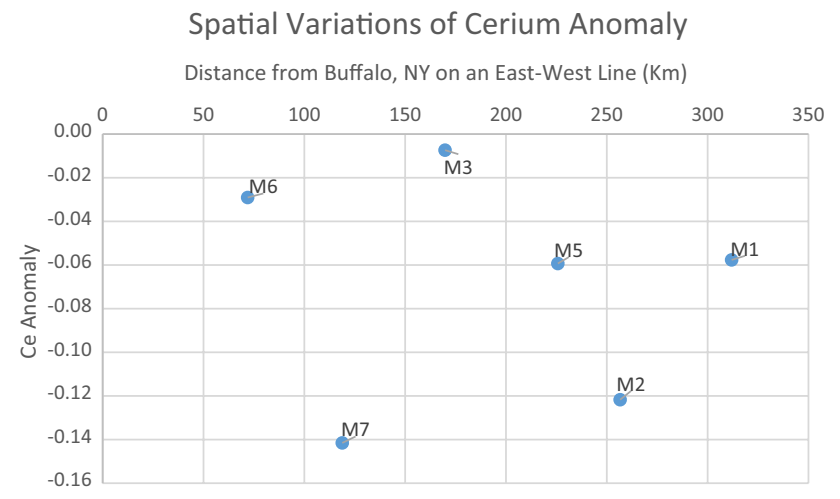

Fig. 7 Variations in the Ce anomaly along the west to east transect across New York State. This indicates varying degrees of anoxia within the basin which may be related to the local water depth or depositional environment

window and agrees with the expectation by Bruner and Smosna (2011) for the Marcellus in Central and Western New York. The second possibility is that the terrestrial organic material has been thermally matured to a CPI of one (El Nemr et al. 2016). $n$-Alkanes can breakdown through demethylation, a process where a terminal methyl group is cleaved and replaced with a hydrogen atom. Demethylation of n-alkanes occurs naturally through microbial degradation and can affect the organic chemistry of oil and gas (Guo et al. 2020). The loss of methyl groups results in artificially low CPI values that do not accurately represent the initial organic material composition. The distribution of chain lengths in our samples, however, agrees with the first possibility, and the relative abundances of n-alkanes in M3 best demonstrate this. M3 has two distinct peaks centered around chain lengths $17-18$ and 25-26, clearly showing two different sources of organic material. These two peaks would not be as distinct if the organic material was degraded.

The smaller peaks consisting of shorter $n$-alkane chain lengths in samples M1, M3, M6 and M7 indicate that the source of the marine component of the hydrocarbons is largely phytoplankton and algal (Sikes et al. 2009). While phytoplankton and algae are sources of high hydrocarbon potential, the sample's potential would be dominantly controlled by the overwhelming amount of terrigenous organic material. While type II kerogen (mixture of marine and terrigenous organic material) has a higher hydrocarbon potential than type III kerogen (solely terrigenous organic material), it is unknown if the amount of marine organic material present is sufficient to have a positive impact on gas potential.

The source of the terrestrial component of the hydrocarbons for all samples was determined to be terrigenous plants because of the abundance of longer $n$-alkane chains within the samples (Bianchi and Canuel 2011). The terrigenous organic material, sourced from eastern New York, was transported along the Acadian mountains-Catskill delta sediment route. Terrigenous plants were also determined to be the source of the terrestrial OM of the Cretaceous black shales from the eastern edge of Cape Verde Basin analyzed in Simoneit (1997) which had similar chain lengths in their study.

The three n-alkane proxies do not indicate any large variations in the sources or maturity of the shale OM. While there are differences in peak distributions between the samples, the differences in marine peak size may not be enough to change the proxy values due to a much larger terrigenous peak. A spatial trend in percent total lipids with an $R^{2}$ of 0.5159 is observed, where the percent total lipids increase toward the east (Fig. 4). This trend would support what is being observed in the source of the organic material. Since the source of sediment is coming from the eroding Acadian Mountains, it would be expected that higher amounts of terrigenous organic material would be deposited closer toward the Acadian Mountains in the East. A larger sample size is needed to further investigate this possible trend. 
Table 5 Results from the inorganic analysis shown below

\begin{tabular}{lllllll}
\hline & M6 & M7 & M3 & M5 & M2 & M1 \\
\hline Ce anomaly & -0.03 & -0.14 & -0.01 & -0.06 & -0.12 & -0.06 \\
TOM (Wht\%) & 7.27 & 2.43 & 7.59 & 3.68 & 14.46 & 3.02 \\
Ni (mg/kg) & 86 & 13 & 114 & 59 & 297 & 55 \\
\hline
\end{tabular}

The Cerium Anomaly does not have a unit associated with it, the Total Organic Matter (TOM), was calculated through Loss On Ignition (LOI), and the amount of Nickel within each sample is reported by (mg/kg)
The cerium anomalies for most samples were negative, indicating that the basin was under anoxic conditions during deposition (Quinby-Hunt et al. 1989). However, M3 and M6 are considered to be deposited during suboxic conditions because the anomalies are close to zero. This is consistent with Werne et al. (2002), who determined that the lower Oatka Creek Formation of the Marcellus was deposited under anoxic conditions. However, there is no clear trend in anoxic values across the basin. This could be because of varying depth within the basin, with areas that were shallower and thus suboxic compared to deeper anoxic portions of the basin. Further 3D stratigraphic controls are needed to better understand anoxic conditions across the basin.

The TOM also did not show any spatial trends across New York State. A correlation between nickel and TOM was found with an $R^{2}$ value of 0.945 . This indicates that algae were the most probable source of the marine sourced organic material, which supports the results from the lipid biomarkers. (Lewan and Maynard 1982).

Based on the results of the inorganic and organic analysis, it was determined that the kerogen type of the Marcellus Formation in New York State was type III (Table 1). This is because the source of the organic material is primarily terrigenous plants. Type III kerogen is consistent with the results of Nyahay et al. (2007), who also studied the Marcellus Formation in New York State. In other locations of the Appalachian basin, the kerogen type of the Marcellus

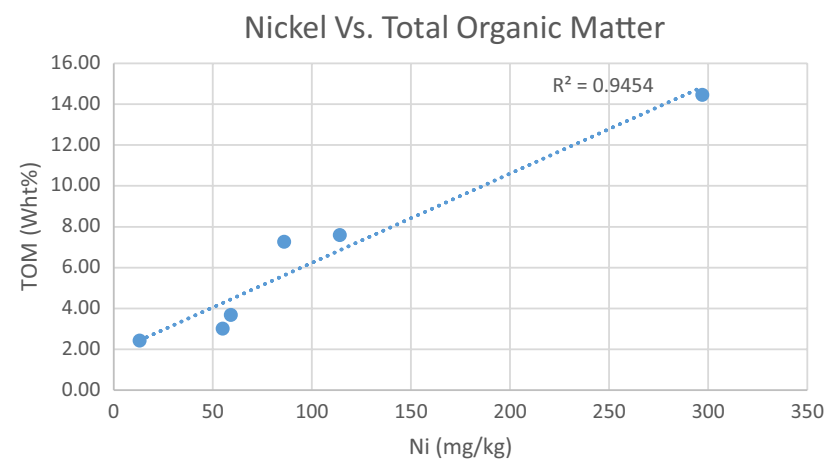

Fig. 8 The relationship between Ni and TOM is significant and suggests that algae is a probable source for the organic matter in the shale (Lewan and Maynard, 1982). An $R^{2}$ of 0.9454 was determined for the line of best fit describing the relationship between $\mathrm{Ni}$ and TOM has been determined to be type II or type III (Agrawal and Sharma, May 2018, Obermajer et al. 1997, Pernia et al. 2015). There is also a smaller component of marine input which is phytoplankton and algal in origin. The CPI suggests that the hydrocarbons within the samples are mature enough to produce petroleum along the sampled transect.

\section{Conclusion}

Overall, there were no major spatial variations when looking at the organic material of the Marcellus Formation. There was a slight apparent trend where the total amount of lipids was shown to increase as you go east across New York State (Fig. 4). The ACL for all samples was calculated to be $\sim 25$, and the ATR for all samples was calculated to be less than 1 . These values indicate that the organic material within the Marcellus in New York State is primarily terrestrial in origin. There is also a marine sourced component contributing to the organic material within the samples (Fig. 5). Based on the ACL and the other longer chain lengths within the samples, it was determined that the source of the terrestrial organic material was terrigenous plants, and the source of the marine organic material was determined to be phytoplankton and algal because of the abundance of shorter chain lengths around 15-17. The calculated CPI values within the samples were around one and indicates that the samples have been matured enough indicating that the Marcellus Formation in New York should produce petroleum.

The calculated cerium anomalies for each sample were all negative, indicating that the basin was anoxic during deposition. Two samples, however, M3 and M6, were close to zero and can be considered suboxic (Fig. 7). A correlation between nickel and TOM was observed and indicates that the source of the marine input of the organic material is algal. This supports what was observed from the lipid biomarker analysis. TOM and anoxia did not show any spatial trends across the basin. This could be because there was varying local depth within the basin across New York causing anoxia and TOM to vary across the entire basin. Overall, the Marcellus Formation in New York State was determined to contain type III kerogen and could prove to be an economic asset to New York in the future.

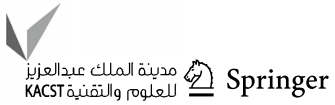


Funding Research for this project was partially supported by Global Aquatic Research LLC, and the Student Undergraduate Research Program at SUNY Brockport.

\section{Data and material availability Data transparency.}

Code availability Software application or custom code.

\section{Declarations}

Conflicts of interest The author declare that they have no conflict of interest.

Open Access This article is licensed under a Creative Commons Attribution 4.0 International License, which permits use, sharing, adaptation, distribution and reproduction in any medium or format, as long as you give appropriate credit to the original author(s) and the source, provide a link to the Creative Commons licence, and indicate if changes were made. The images or other third party material in this article are included in the article's Creative Commons licence, unless indicated otherwise in a credit line to the material. If material is not included in the article's Creative Commons licence and your intended use is not permitted by statutory regulation or exceeds the permitted use, you will need to obtain permission directly from the copyright holder. To view a copy of this licence, visit http://creativecommons.org/licenses/by/4.0/.

\section{References}

Agrawal V, Sharma S (2018) Testing utility of organogeochemical proxies to assess sources of organic matter, paleoredox conditions and thermal maturity in mature Marcellus Shale. Frontiers in Energy Research 6:42

Agrawal V, Sharma S (2018) Molecular characterization of kerogen and its implications for determining hydrocarbon potential, organic matter sources and thermal maturity in Marcellus Shale. Fuel 228:429-437

Ayyıldız T, Varol B, Karakaş Z, Sözeri K (2019) Basic geochemical characteristics of lacustrine rocks in the Neogene KağızmanTuzluca Basin, Northeastern Turkey. Journal of Petroleum Exploration and Production Technology 9(1):141-157

Bianchi TS, Canuel EA (2011) Chemical biomarkers in aquatic ecosystems. Princeton University Press

Bianchi TS, Schreiner KM, Smith RW, Burdige DJ, Woodard S, Conley DJ (2016) Redox effects on organic matter storage in coastal sediments during the Holocene: A biomarker/proxy perspective. Annu Rev Earth Planet Sci 44:295-319

Bligh EG, Dyer WJ (1959) A rapid method of total lipid extraction and purification. Can J Biochem Physiol 37(8):911-917

Bray EE, Evans ED (1961) Distribution of n-paraffins as a clue to recognition of source beds. Geochim Cosmochim Acta 22(1):2-15

Bruner KR, Smosna R (2011) A comparative study of the Mississippian Barnett shale, Fort Worth Basin, and Devonian Marcellus shale. Appalachian Basin 106

Canuel EA, Martens CS (1993) Seasonal variations in the sources and alteration of organic matter associated with recently-deposited sediments. Org Geochem 20(5):563-577

Chen R, Sharma S (2016) Role of alternating redox conditions in the formation of organic-rich interval in the Middle Devonian
Marcellus Shale, Appalachian Basin, USA. Palaeogeogr Palaeoclimatol Palaeoecol 446:85-97

Didyk BM, Simoneit BRT, Brassell ST, Eglinton G (1978) Organic geochemical indicators of palaeoenvironmental conditions of sedimentation. Nature 272(5650):216

Driese SG, Mora CI, Elick JM (1997) Morphology and taphonomy of root and stump casts of the earliest trees (Middle to Late Devonian), Pennsylvania and New York, USA. Palaios 12(6):524-537

Eglinton G, Hamilton RJ (1967) Leaf epicuticular waxes. Science 156(3780):1322-1335

El Nemr A, Moneer AA, Ragab S, El Sikaily A (2016) Distribution and sources of $n$-alkanes and polycyclic aromatic hydrocarbons in shellfish of the Egyptian Red Sea coast. The Egyptian Journal of Aquatic Research 42(2):121-131

Gao Y, Wen Z, Xu Y, Song H, Li W, Yu Y, Ke C (2020) Geochemical characteristics of the Chang7 organic-rich fine-grained sedimentary rocks and its relationship with the tight oil in Longdong area, Northwest China. J Pet Explor Prod Technol 1-14

Grice K, Eiserbeck C (2013) The analysis and application of biomarkers. In Treatise on geochemistry. Elsevier Science, p 47-78

Griffing DH, Ver Straeten CA (1991) Stratigraphy and depositional environments of the lower part of the Marcellus Formation (Middle Devonian) in eastern New York State. In New York State Geological Association 63rd Annual Meeting, SUNY Oneonta, p 205-234

Guo H, Tang S, Xie S, Wang P, Huang C, Geng X, Fang J (2020) The oil removal and the characteristics of changes in the composition of bacteria based on the oily sludge bioelectrochemical system. Sci Rep 10(1):1-10

Jeng WL (2006) Higher plant n-alkane average chain length as an indicator of petrogenic hydrocarbon contamination in marine sediments. Mar Chem 102(3-4):242-251

Kargbo DM, Wilhelm RG, Campbell DJ (2010) Natural gas plays in the Marcellus Shale: Challenges and potential opportunities. Environ Sci Technol 44(15):5679-5684

Kennicutt MC II, Barker C, Brooks JM, DeFreitas DA, Zhu GH (1987) Selected organic matter source indicators in the Orinoco Nile and Changjiang Deltas. Organic Geochemistry 11(1):41-51

Kostecki P, Morrison R, Dragun J (2005) HYDROCARBONS. Encyclopedia of Soils in the Environment, 217-226

Lash GG, Engelder T (2011) Thickness trends and sequence stratigraphy of the Middle Devonian Marcellus Formation, Appalachian Basin: Implications for Acadian foreland basin evolution. AAPG Bull 95(1):61-103

Lewan MD, Maynard JB (1982) Factors controlling enrichment of vanadium and nickel in the bitumen of organic sedimentary rocks. Geochim Cosmochim Acta 46(12):2547-2560

Mani D, Kalpana MS, Patil DJ, Dayal AM (2017) Organic Matter in Gas Shales: Origin, Evolution, and Characterization. In Shale Gas, p 25-54

Mazzullo SJ (1973) Deltaic depositional environments in the Hamilton Group (Middle Devonian, southeastern New York state). J Sediment Res 43(4):1061-1071

Meyers PA (1997) Organic geochemical proxies of paleoceanographic, paleolimnologic, and paleoclimatic processes. Org Geochem 27(5-6):213-250

Meyers PA, Ishiwatari R (1993) The early diagenesis of organic matter in lacustrine sediments. In Organic geochemistry. Springer, Boston, MA. p 185-209

Miceli Romero A, Philp RP (2012) Organic geochemistry of the Woodford Shale, southeastern Oklahoma: How variable can shales be? AAPG Bull 96(3):493-517

Mißbach H, Duda JP, Lünsdorf NK, Schmidt BC, Thiel V (2016) Testing the preservation of biomarkers during experimental maturation of an immature kerogen. Int J Astrobiol 15(3):165 
Nyahay RE, Leone J, Smith LB, Martin JP, Jarvie DJ (2007) Update on Regional Assessment of Gas Potential in the Devonian Marcellus and Ordovician Utica Shales of New York, Thirty-Sixth Meeting of the Eastern Section. American Association of Petroleum Geologists, Lexington, KY.

Obermajer M, Fowler MG, Goodarzi F, Snowdon LR (1997) Organic petrology and organic geochemistry of Devonian black shales in southwestern Ontario Canada. Organic Geochemistry 26(3-4):229-246

Pernia D, Bissada KA, Curiale J (2015) Kerogen based characterization of major gas shales: Effects of kerogen fractionation. Org Geochem 78:52-61

Peters KE, Walters CC, Moldowan JM (2005) The biomarker guide, I: Biomarkers and isotopes in the environment and human history, 2nd edn. Cambridge University Press. Cambridge, UK

Popova O, Frye E, Panarelli E (2015).Updated geologic maps provide greater detail for Marcellus formation. https://www.eia. gov/todayinenergy/detail.php?id=20612\#. Retrieved 19 July 2020

Poynter J, Eglinton G (1990) Molecular composition of three sediments from hole 717c: The Bengal fan. In Proceedings of the Ocean Drilling Program: Scientific results, vol 116, p 155-161

Qu J, Ding X, Zha M, Chen H, Gao C, Wang Z (2017) Geochemical characterization of Lucaogou Formation and its correlation of tight oil accumulation in Jimsar Sag of Junggar Basin, Northwestern China. Journal of Petroleum Exploration and Production Technology 7(3):699-706

Quinby-Hunt MS, Wilde P, Orth CJ, Berry WBN (1989) Elemental geochemistry of black shales-statistical comparison of lowcalcific shales with other shales. Metalliferous Black Shales and Related Ore Deposits. US Geol Surv Circ 1037:8-15
Sikes EL, Uhle ME, Nodder SD, Howard ME (2009) Sources of organic matter in a coastal marine environment: evidence from $\mathrm{n}$-alkanes and their $\delta 13 \mathrm{C}$ distributions in the Hauraki Gulf New Zealand. Marine Chemistry 113(3-4):149-163

Simoneit BRT (1977) Leg 41 sediment lipids-Search for eolian organic matter in Recent samples and examination of a black shale. Init Rep Deep Sea Drilling Proj 41:855-858

Smith LB, Schieber J, Wilson RD (2019) Shallow-water onlap model for the deposition of Devonian black shales in New York, USA. Geology 47(3):279-283

Theresa NA, Godwin DA, Charles CC, Oguejiofo TU (2018) Comparative assessment of carbon preference index and degree of waxiness in different crude oils as indicator of maturity and organic matter input: a case study of Ebocha and Kwali crude oil Niger Delta, Nigeria. Recent Adv Petrochem Sci 4(1):555630

Tissot BP, Pelet R, Ungerer PH (1987) Thermal history of sedimentary basins, maturation indices, and kinetics of oil and gas generation. AAPG Bull 71(12):1445-1466

Werne JP, Sageman BB, Lyons TW, Hollander DJ (2002) An integrated assessment of a "type euxinic" deposit: evidence for multiple controls on black shale deposition in the Middle Devonian Oatka Creek Formation. Am J Sci 302(2):110-143

Xie YL, Dearing JA, Blomendal I (2000) Organic matter content of street dust in Liverpool, UK and its association with dust magnetic properties. Atmos Environ 34:269-275

Publisher's Note Springer Nature remains neutral with regard to jurisdictional claims in published maps and institutional affiliations. 